\title{
Spatial inequalities of COVID-19 incidence and associated socioeconomic risk factors in Portugal
}

\author{
Desigualdades espaciales de la incidencia de COVID-19 \\ y factores de riesgo socioeconómico asociados en Portugal
}

\author{
Ricardo Almendra \\ ricardoalmendra85@gmail.com \\ Paula Santana \\ paulasantana@uc.pt \\ Claudia Costa \\ claudiampcosta@gmail.com \\ Department of Geography and Tourism \\ University of Coimbra (Portugal)
}

\begin{abstract}
COVID-19 hit the world in a sudden and uneven way. Scientific community has provided strong evidence about socioeconomic characteristics of the territory associated with the geographical pattern of COVID-19 incidence. Still, the role played by these factors differs between study areas. Geographically Weighted Regression (GWR) models were applied to explore the spatially varying association between age-standardized COVID-19 incidence rate in 2020 and socioeconomic conditions in Portugal, at the municipality level. The spatial context was defined as a function of the number of neighbours; the bandwidth was determined through AIC. Prior, the
\end{abstract}


validity of the GWR was assessed through ordinary least squares models. Border proximity, proportion of overcrowded living quarters, persons employed in manufacturing establishments and persons employed in construction establishments were found to be significant predictors. It was possible to observe that municipalities are affected differently by the same factor, and that this varying influence has identifiable geographical patterns, the role of each analysed factor varies importantly across the country. This study provides useful insights for policymakers for targeted interventions and for proper identification of risk factors.

Key words: COVID-19; geographical patterns; socioeconomic disparities; spatial analysis.

\section{Resumen}

COVID-19 golpeó al mundo de manera repentina y desigual. La comunidad científica ha aportado pruebas sobre las características socioeconómicas del territorio asociadas al patrón geográfico de incidencia de COVID-19. Se aplicaron modelos de regresión ponderada geográficamente (GWR) para explorar la asociación espacialmente variable entre la tasa de incidencia de COVID-19 estandarizada por edad y las condiciones socioeconómicas (viviendas superpobladas, capacidad en unidades de atención social para ancianos, trabajadores de la construcción y manufactura, proximidad de la frontera y personas que se desplazan para un municipio). El contexto espacial se definió en función del número de vecinos; el ancho de banda se determinó mediante AIC. Previamente se evaluó el GWR mediante modelos de mínimos cuadrados ordinarios. La proximidad de la frontera, la proporción de viviendas superpobladas, las personas empleadas en establecimientos manufactureros y las personas empleadas en establecimientos de construcción resultan ser predictores significativos. Se pudo observar que los municipios se ven afectados diferentemente por el mismo factor y que esta influencia variable tiene patrones geográficos identificables, el papel de cada factor analizado varía de manera importante a lo largo del país. Este estudio proporciona información útil para los formuladores de políticas para intervenciones específicas y para la identificación adecuada de factores de riesgo.

Palabras clave: COVID-19; patrones geográficos; disparidades socioeconómicas; análisis espacial. 


\section{Introduction}

Since the start of the pandemic, an estimated 170 million people have been infected worldwide, and 3.5 million have died, demonstrating the extent to which the world was ill-prepared to respond to a global health emergency (Timmis \& Brüssow, 2020). With the increasing number of patients in need of medical assistance the healthcare services struggle to give appropriate answer worldwide (Mollalo et al., 2020; Volpato et al., 2020). According to the United Nations' biodiversity panel it is likely that in the future pandemics will happen more often, kill more people and cause even worse damage to the global economy than COVID-19 (Daszak et al., 2020).

Population mobility was firstly considered the most relevant factor to explain the rapid spread of COVID-19, both daily commuting (Kang et al., 2020), international travels (Adegboye et al., 2021; Almeida et al., 2020) and large-scale migrations (Adegboye et al., 2020). With increased knowledge about COVID-19, several other factors have been identified to play a decisive role in the spread of the disease (da Costa \& da Costa, 2020; Ribeiro \& Santos, 2020).

The number of studies addressing the associations between the epidemic incidence and possible explanatory factors has increased significantly during the last months, covering different spaces, at different scales and assessing different indicators. Li et al. (Li et al., 2020) assessed the role played by urban infrastructures to explain the severity of cases across Wuhan. Murgante et all (2020) explained why Italy was so seriously hit though geographical and climatic similarities among the areas. Mogi and Spijker (Mogi \& Spijker, 2021) analysed the influence of social and economic ties to the spread of COVID-19 in Europe at the country level. Mollalo, Vahedi, and Rivera (2020) used environmental, socioeconomic, topographic, and demographic variables to model the COVID-19 incidence in the United States of America, at the county-level. Kulu and Dorey (2021) calculated the cumulative infection rates in Great Britain by local authority districts and council areas identifying that infection rate increased with the population density and with the level of deprivation. Menéndez and Higueras Garcia (2020) looked within the city of Madrid and found that there was a major concentration of cases in the peripheral areas rather than in the city centre.

There is ample evidence that health inequities have a spatial footprint, often following the geographical patterns of inequality in the social, economic, built and physical environment in which people are born, grow, live, work, and age (Chung et al., 2020; Huisman et al., 2005; Loureiro et al., 2019; Santana et al., 2020; Santana et al., 2015; Santana \& Almendra 2019; Wang \& Tang, 2020). Conditions favouring the infection are clustered within social groups 
according to the inequality patterns of our societies, exacerbating the syndemic nature of the threat (Horton, 2020). People living in poorly ventilated, poorly built and crowded dwellings are at higher risk as these characteristics favour transmissible diseases (Team \& Manderson, 2020). Individuals in low-income jobs are the most affected and vulnerable to death and infection related to COVID-19 (Sannigrahi et al., 2020) due to a greater prevalence of precarious employment conditions, impossibility to homework, and work environments that favour close contact between colleagues (Pasco et al., 2020).

Urban areas characterized with higher population and economic densities are also recognized as factors favouring the COVID-19 transmission due to its higher concentration of individuals, residential blocks, shopping amenities and constant demand of mass transportations of goods (Li et al., 2020). Places where people gather and concentrate are the principal locations for the transmission between humans, providing the perfect context for the interaction of the drivers of transmission (Almendra et al., 2021; Dalziel et al., 2018; Sharifi \& Khavarian-Garmsir, 2020). Urban areas tend to present higher concentration of atmospheric pollutants and according to Conticini, Frediani and Caro (2020) the predisposition to infection is higher among individuals more exposed to air pollution.

Population age structure is considered a crucial factor to explain deaths and infection as physical and social vulnerability may be linked with increased incidence and lethality (Almendra et al., 2021; Dowd et al., 2020; Sannigrahi et al., 2020). COVID-19 outbreak in retirement homes and long-term facilities for dependent elderly have been reported as having devastating impacts as the contacts between residents and nursing staff are frequent and unavoidable so it is extremely difficult to stop the spread of the disease inside the facility (Etard et al., 2020); further, high mortality rates in older persons living in nursing homes have been reported (Gardner et al., 2020).

Apart from the socio-demographic factors, other environmental conditions such as air quality (Murgante et al., 2020; Zhu et al., 2020), humidity (Sanchez-Lorenzo et al., 2021), temperature (Murgante et al., 2020; Sanchez-Lorenzo et al., 2021; Smit et al., 2020), seasonal climatic variability (Sironi et al., 2020; Smit et al., 2020) and atmospheric circulation characteristics (Sanchez-Lorenzo et al., 2021; Setti et al., 2020) could influence the transmission of COVID-19 and be responsible for spatial disparities across and between countries.

The COVID-19 outbreak has forced governments to give immediate answers to an emergency that is seriously threatening not only population health but also social cohesion, the economy and 
the infrastructures of territories. The intensity and type of measures applied, as well as the timing of their execution (Dowd et al., 2020) and their health governance (Chung et al., 2020), are likely to influence the evolution of the COVID-19 spread and the incidence geographical pattern. Although in different timings, governments often decided for the implementation of measures such as stricter border management policies, cancelling public events, closing day care centres, schools and universities, promoting social distancing, telework or partial or total lockdowns (Flaxman et al., 2020; Mogi \& Spijker, 2021). Despite all the efforts taken, the virus spread without being stopped by political borders (Chung et al., 2020).

Marques et al (2021) analysed the first 100 days of COVID progression in Portugal and found that the diffusion process started in more populated and economically active areas, following the frontier areas, and later, it spread to lower density and ageing territories.

It is undeniable that the COVID-19 crisis is having multifaceted impacts on people and communities. Constant fear and worry, as well as other stressors and insecurities felt during the pandemic can have severe impacts on physical and mental health (Brooks et al., 2020; Knudsen et al., 2021; Wang et al., 2020). The role played by the multiple factors influencing the evolution of the disease is not even throughout the space (Moniz, Soares, and Nunes 2021). A specific factor can be of extreme relevance in a certain location but can be negligible in others, or even impact the disease progression in an opposite way. Understanding the spatial patterns of the influence of these factors could contribute to the gathering of valuable knowledge for controlling the outbreak by informing more precise strategy adapted for different areas to better tackle future similar public health emergencies (Ribeiro \& Santos, 2020). Thus, this study aims to assess the spatial inequalities of COVID-19 incidence in Mainland Portugal (hereinafter referred as Portugal) in 2020 and analyse which and how the impacts of socioeconomic conditions vary across the country. To our best knowledge, this paper provides the first attempt to use GWR models of COVID-19 distribution across Portugal and can provide useful insights for policymakers for targeted interventions and for proper identification of risk factors.

\section{Data and methods}

\section{1 Study area}

This study focuses on the municipalities from Portugal (Figure 1). The units of analysis were the 278 municipalities of Portugal mainland (i.e. hence excluding the islands of Madeira and the Azores). Portuguese municipalities are considered to present internal homogeneity as their 
socioeconomic characteristics are more likely to reflect the nature of the social environment where people live (Santana et al., 2015). Moreover, this administrative level is considered the geographical level that better fits ecological studies in Portugal, based on national registries (Roquette et al., 2018).

Figure 1. Location of the Portuguese municipalities within the Iberian Peninsula

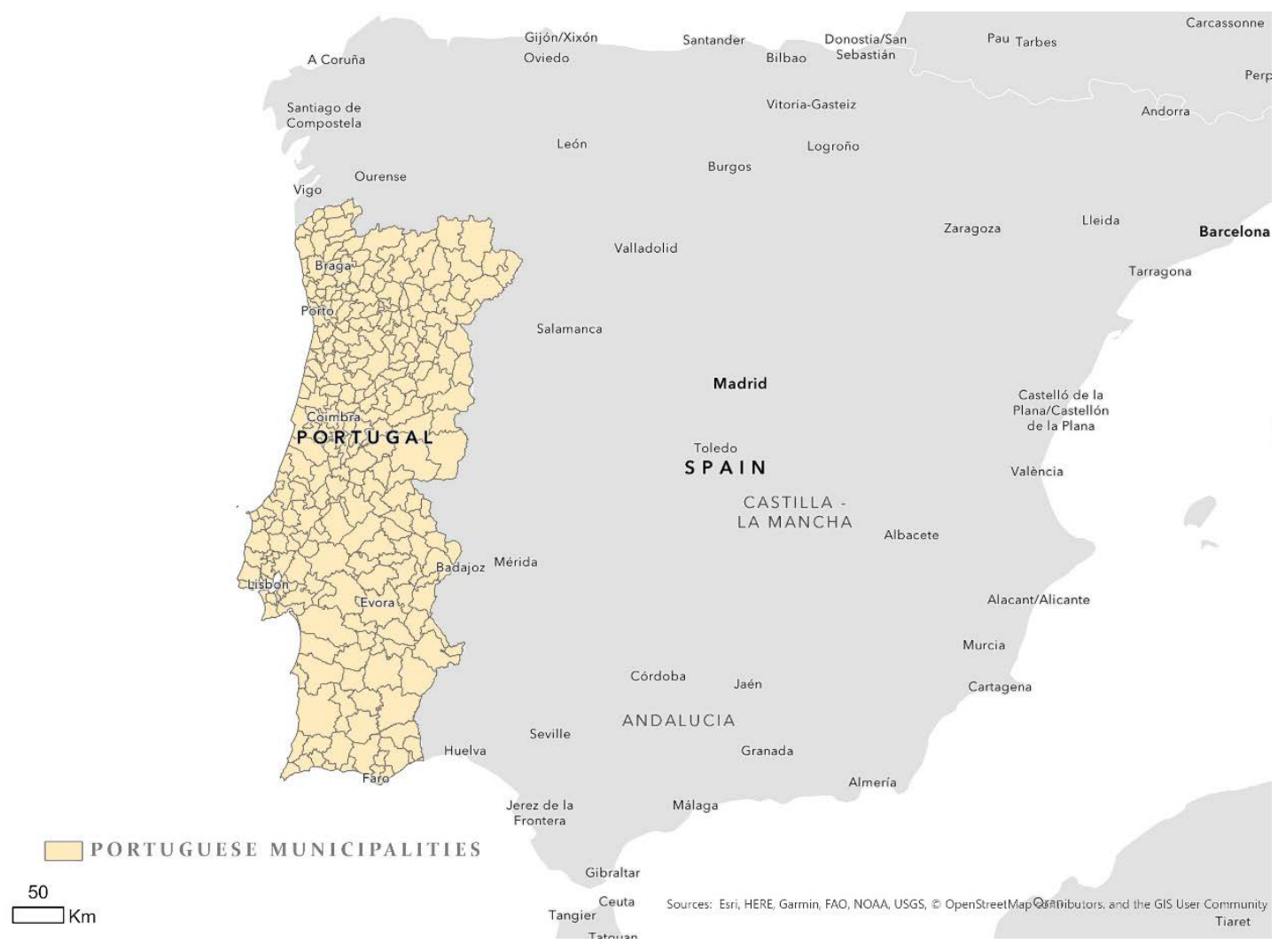

Source: own elaboration with data from EUROSTAT and General-Director of Territory (2021)

In 2019, the Portuguese resident population was almost 10 million inhabitants, $70 \%$ of whom reside in urban spaces (Santana \& Almendra, 2018). Nonetheless, although population living in urban areas is increasing in Portugal, the share of the population living in rural areas is still high compared to other European Countries (OECD, 2018).

Lisbon and Porto are the two most populous cities and the capitals of the correspondent metropolitan areas, accounting together for nearly 4.5 million inhabitants (both Metropolitan areas). 


\subsection{Data collection and processing}

a) Dependent variable

COVID-19 incidence data (from March to December 2020) was provided by the Portuguese Directorate-General of Health through a protocol. The database stores information about all the persons that were tested positive for COVID-19, namely the date of the test, the municipality of Residence, sex, age and symptoms.

Age-standardized COVID-19 incidence rate was calculated for each municipality accordingly to the direct standardization method. Estimated population produced by the Portuguese National Statistics to 2019 and European standard population was used.

\section{b) Independent variables}

To analyse how the impacts of socioeconomic conditions on COVID-19 incidence vary across the country, six variables from four dimensions were selected. The dimensions are: built environment, social care, employment and mobility. The six variables, presented in Table 1, were collected at municipality level for the most recent year available.

Table 1. Dependent variables and data sources

\begin{tabular}{|c|c|c|c|}
\hline DIMENSION & VARIABLES & $\begin{array}{c}\text { REFERENCE } \\
\text { PERIOD }\end{array}$ & DATA SOURCE \\
\hline $\begin{array}{c}\text { Built } \\
\text { Sonvironment }\end{array}$ & $\begin{array}{c}\text { Proportion of overcrowded living } \\
\text { quarters (\%) }\end{array}$ & 2011 & National Statistics \\
\hline \multirow{2}{*}{ Employment } & $\begin{array}{c}\text { Social care units' beds } \\
(/ 100.000 \text { elders) }\end{array}$ & 2018 & $\begin{array}{c}\text { Ministry of Labour and } \\
\text { Social Security; } \\
\text { National Statistics }\end{array}$ \\
\cline { 2 - 5 } & $\begin{array}{c}\text { Persons employed in } \\
\text { manufacturing establishments (\%) }\end{array}$ & 2019 & National Statistics \\
\hline Mobility & $\begin{array}{c}\text { Pestablishments (\%) } \\
\text { municipality to work or study (\%) }\end{array}$ & 2019 & National Statistics \\
\cline { 2 - 5 } & $\begin{array}{c}\text { Time to reach the Border with } \\
\text { Spain, weighted by population } \\
\text { distribution }\end{array}$ & 2020 & National Statistics \\
\hline
\end{tabular}

Source: authors' own elaboration

The proportion of overcrowded living quarters, and of people commuting to the municipality to work or study are calculated by the Portuguese National Statistics Office, based on the Census data from 2011. The proportion of people employed in manufacturing establishments or in 
construction establishments are also calculated by the national statistics, based on data from 2019 collected through their integrated business accounts system. The dimension Social care is analysed through the capacity of residential units for elderly support with an agreement with social services per 100.000 inhabitants with more than 65 years old. The capacity of the units is provided by the Ministry of Labour and Social Security through the Carta Social website while the estimated population by age group was taken from the National Statistics Office. The border proximity is measured by the time needed by each Portuguese statistical unit to reach the closest Spanish statistical unit. Since this indicator is based on spatial data, the closest facility tool and the road network provided by ArcGIS PRO were required to build the indicator. After running this tool, the time of each statistical subsection was weighted by the number of people living there and the distribution of the population within the municipality. The methodology applied to build this indicator follows the one published by Costa et al. (2020).

\subsection{Methodology}

Both a global (Ordinary Least Square) and a local (Geographically Weighted Regression) models were applied to assess the association between the COVID-19 incidence and selected socioeconomic factors. The global effects of socioeconomic factors were addressed with the Ordinary Least Squares (OLS) coefficient estimates, assuming that the effects are evenly distributed across the country (Li et al., 2020). OLS model outcomes were also assessed to inform about multicollinearity and the global behaviour of the independent variables. Residual spatial heterogeneity was evaluated through Moran's I. Variables considered important by the literature, despite of being statistically significant, were kept in the model if the model integrity was not threatened.

Geographically Weighted Regression (GWR) models were applied to explore the spatially varying association between age-standardized COVID-19 incidence rate and socioeconomic factors, at the municipality level. When assessing the relationship between the dependent and

independent variable, GWR models estimate as many coefficients as the number of municipalities, allowing the analysis of how the impact of a specific risk factor on the outcome changes across the country (Weisent et al., 2012). Following Tobler's first law of geography, the influence of a given variable decreases with the increase of the distance from spatial unit where the outcome is being measured (Gu et al., 2021). The spatial context was defined as a function of the number of neighbours and the optimal model bandwidth was based on AIC criterion. 
Prior, the validity of the GWR was assessed through ordinary least squares models. The GWR equation adopted is:

$$
Y i=\beta 0\left(\mu_{i}, v_{i}\right)+\sum \beta_{j}\left(\mu_{i}, v_{i}\right) X_{i j}+\varepsilon_{i}
$$

Where $Y_{i}$ indicates the incidence rate at municipality $1 ; X_{i j}$ represents the six independent variables (Proportion of overcrowded living quarters; Social care units' beds; Persons employed in manufacturing establishments; Persons employed in construction establishments; People commuting to the municipality to work or study; Time to reach the Border with Spain, weighted by population distribution); $\beta(\mu \mathrm{i}, \mathrm{i})$ are regression coefficients for the relationship between an explanatory variable and the dependent variable around a location $u$ and is therefore unique to that location, and $i$ is the random error term. The OLS, Moran's I and GWR models were developed on ArcMap 10.8.

\subsection{Data representation}

The indicators, local R2 and coefficients are presented through single choropleth maps produced with ArcGIS PRO.

The age-standardized COVID-19 incidence is represented in five classes quantiles. Darker green represents the municipalities with higher age-standardized COVID-19 incidence.

Regarding the independent variables, the classes for each indicator included in the model were built with the mean and 1 standard deviation. Blue areas identify the municipalities with values below the mean. Brown areas represent the municipalities with values higher than the mean.

Local R2 is represented in seven classes with a 0.1 interval and a darker colour-scheme. The first class, in lighter red, locates the municipalities where the model explains less than 0.10 of COVID19 incidence. The last class, in darker red, locates the municipalities where the model explains more that 0.60 of the dependent variable.

Finally, the coefficients are represented in 7 classes quintiles. Negative coefficients are represented in blue while the positive ones are represented in red. Darker blue means higher negative coefficients. Darker red means higher positive coefficients. 


\section{Results}

\subsection{COVID-19 Incidence rate and socioeconomic factors}

In 2020, near 420 thousand COVID-19 cases were recorded in Portugal, corresponding to an age standardized incidence rate of 3,850.9 cases per 100,000 habitants (and a crude rate of 4,285.3 cases per 100,000 habitants).

In 2020, the so called first and second wave was recorded in Portugal (figure 1). At the end of December, there were already signals of growth, to what became the largest of the waves.

Figure 1. Number of COVID-19 cases in Portugal in 2020

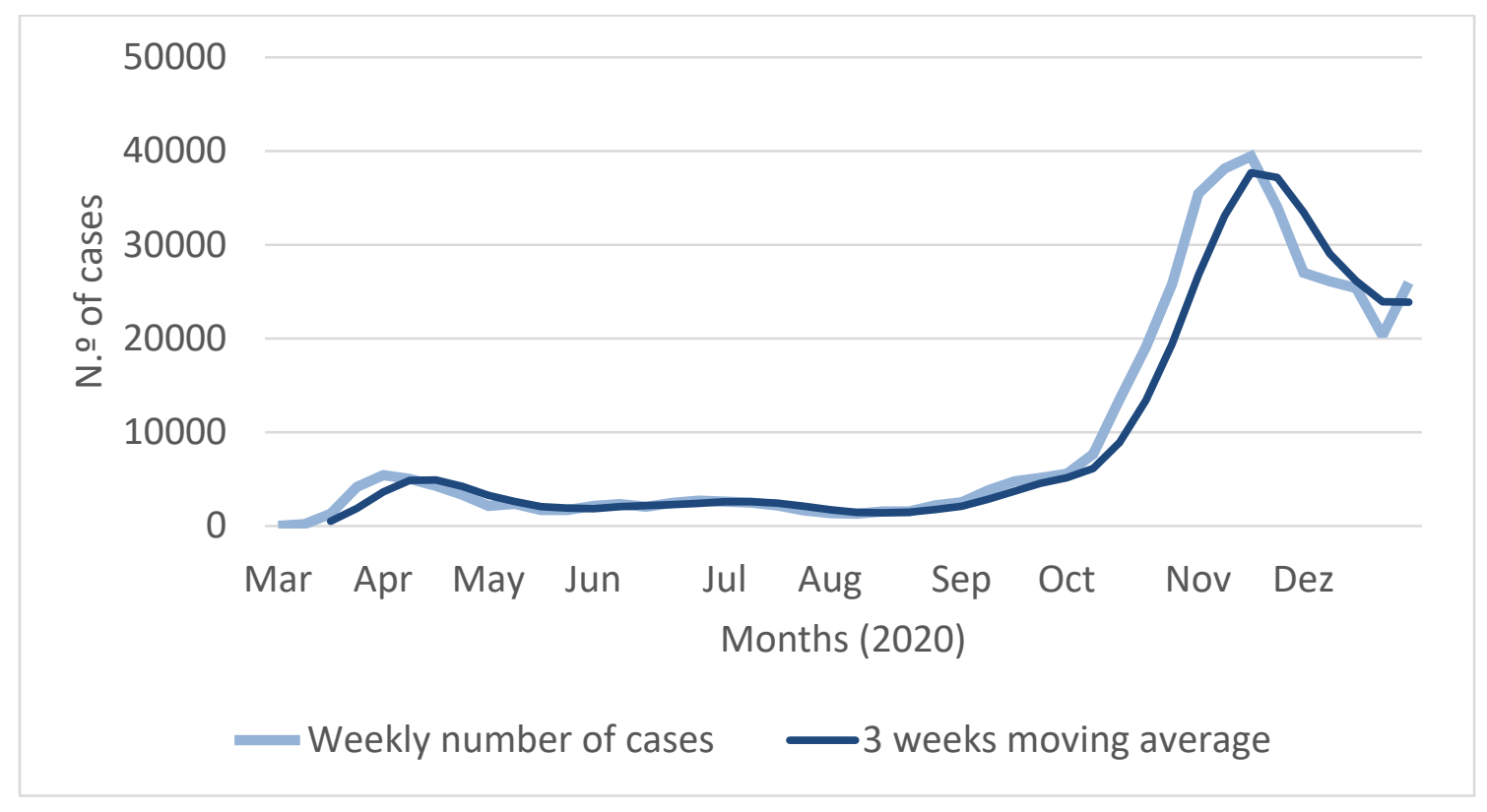

Source: own elaboration based on Directorate-General of Health database for Scientific purposes (2021)

Figure 2 presents the geographical pattern of age-standardized COVID-19 incidence, revealing a heterogeneous spatial pattern with higher incidence rate in the Northern region, along with the Porto Metropolitan Area, near the Atlantic shore, and at the Eastern Spanish border. Municipalities from the South tend to present lower incidence rate. 
Figure 2. Age-standardized COVID-19 incidence

per 100,000 inhabitants and by municipality, 2020

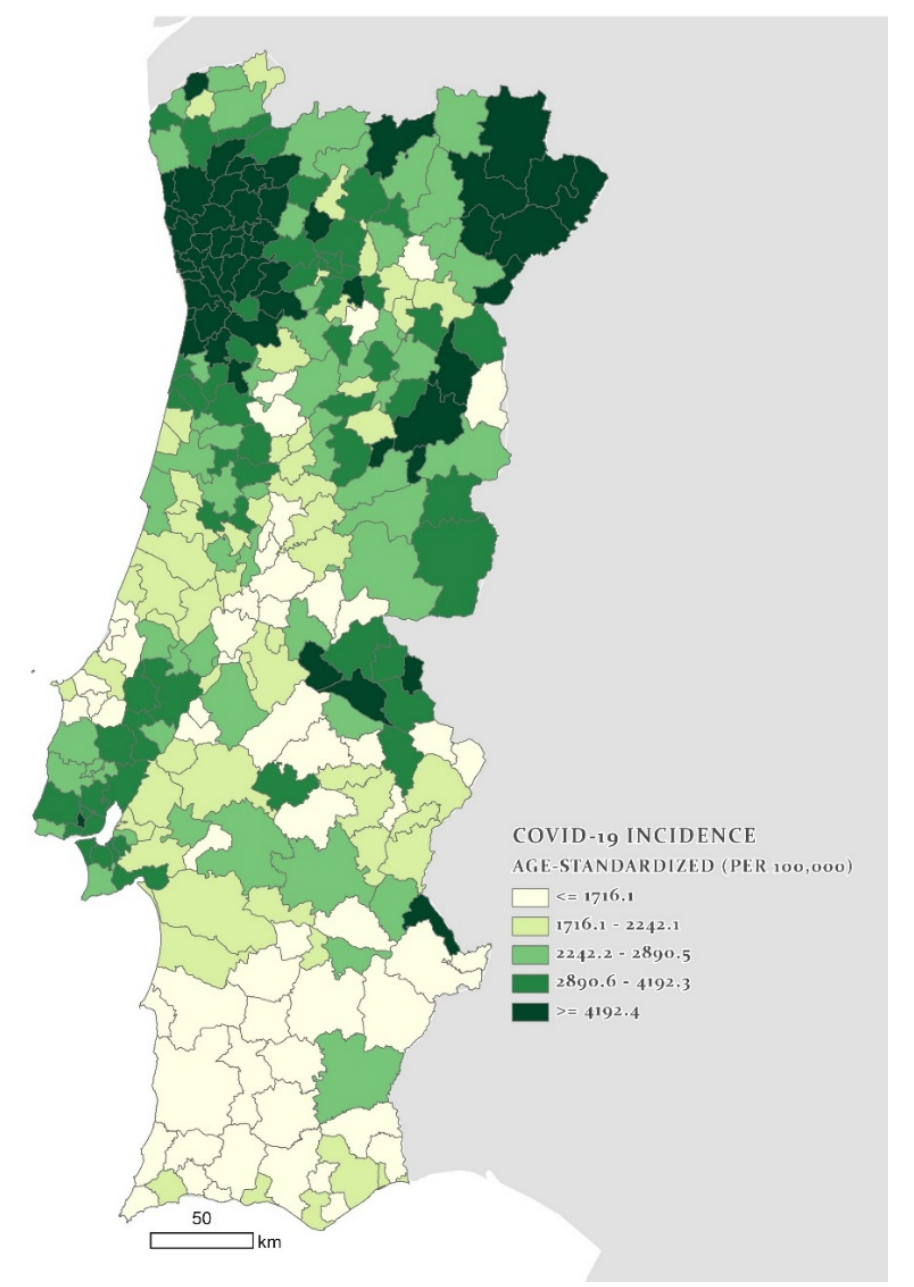

Source: own elaboration based on Directorate-General of Health database for Scientific purposes (2021)

Figure 3 presents the six independent variables assessed. An exploratory analysis of the indicators allows evaluating the geographical pattern of each socioeconomic factor. The indicator time to reach the border with Spain reveals a stronger pattern, and, as it is expected, COVID-19 incidence tends to increase as the distance to Spain diminishes. The ratio of people commuting to the municipality to work or study reveals that municipalities from the two Metropolitan Areas tend to have more people commuting daily. Overcrowded quarters are located mainly in Lisbon and Porto Metropolitan Area and Algarve. The share of people working in Industry companies is higher in the municipalities from the North Atlantic shore, near the Porto Metropolitan Area. Municipalities where the percentage of people working in constructions is higher are located in the Centre and North Regions. The number of social care beds are higher in the municipalities near the border. 
Figure 3. Dependent variables included in the model
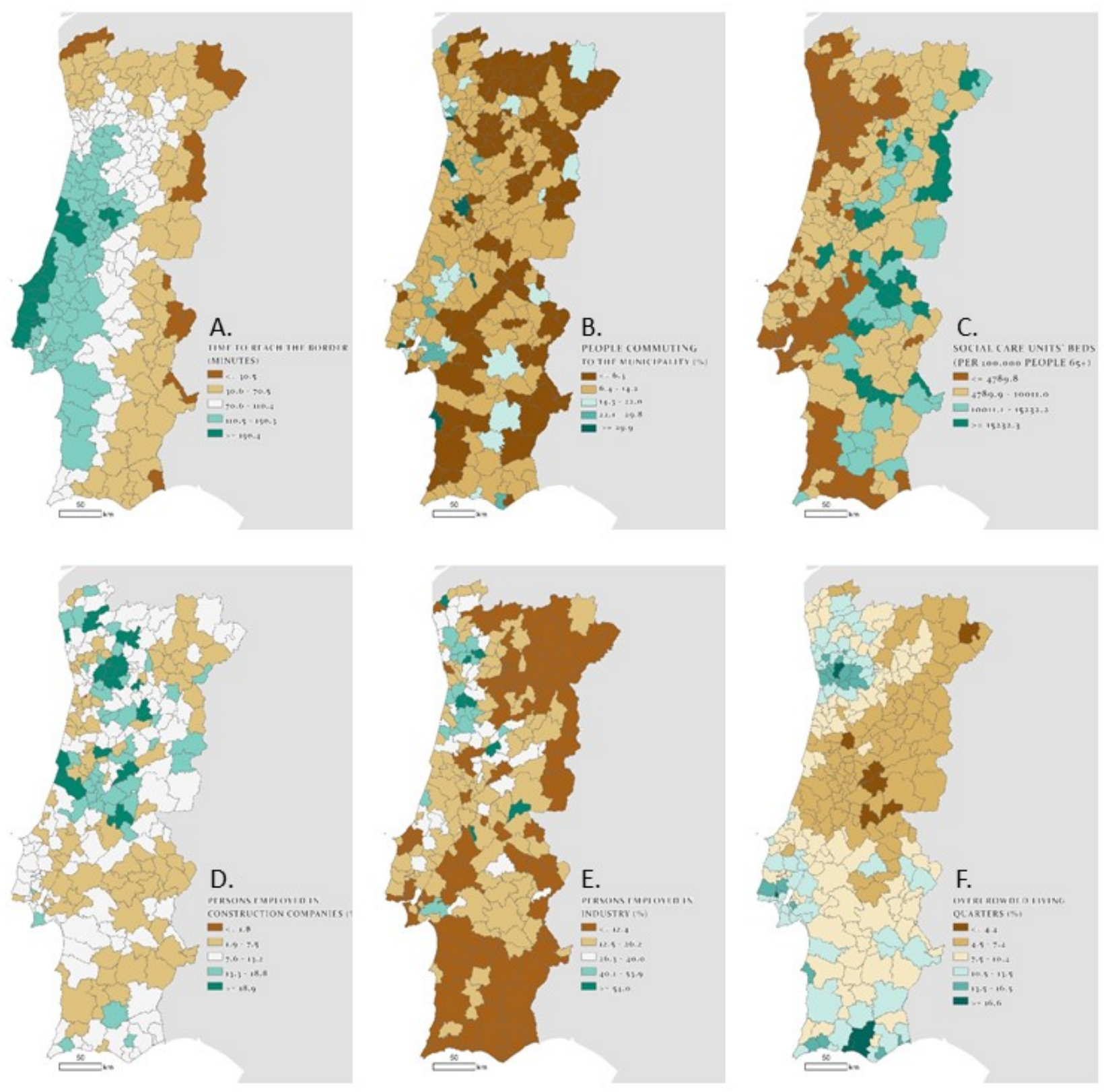

Key: A. Time to reach the Border with Spain, weighted by population distribution; B. People commuting to the municipality to work or study (\%); C. Social care units' beds (/100.000 elders); D. Persons employed in construction establishments (\%); E. Persons employed in manufacturing establishments (\%); F. Proportion of overcrowded living quarters (\%).

Source: authors' own elaboration based on data sources referred on Table 1 


\subsection{OLS Model}

Table 3 indicates the regression results of the global OLS model for the association between COVID-19 incidence and socioeconomic factors. The model presents a moderately low explanatory power with 30\% (AIC of 4847) of the variation explained by the selected factors, among which border proximity, proportion of overcrowded living quarters, persons employed in manufacturing establishments and persons employed in construction establishments are significant at the 99\% confidence level ( $p<0.001$ ). The association between COVID-19 incidence and Social care units' beds and people commuting to the municipality to work or study is not significant, although the direction of the association is accordingly with the expected, as the incidence rises as the distance to Spain decreases and as the commuting movements increase.

Moran's I of the OLS model residuals is significant, meaning that the OLS model with global estimation cannot fully explain the spatial heterogeneity of influencing factors, therefore supporting the adoption of GWR models.

Table 2. OLS model results

\begin{tabular}{|l|c|c|c|c|c|c|}
\hline \multicolumn{1}{|c|}{ VARIABLE } & COEFFICIENTS & $\begin{array}{c}\text { STD. } \\
\text { ERROR }\end{array}$ & $\begin{array}{c}\text { ROBUST } \\
\text { STD. } \\
\text { ERROR }\end{array}$ & $\begin{array}{c}\text { ROBUST T- } \\
\text { STATISTIC }\end{array}$ & $\begin{array}{c}\text { ROBUST } \\
\text { P-VALUE }\end{array}$ & VIF \\
\hline Intercept & 1187,6 & 561,7 & 578,7 & 2,1 & 0,041 & - \\
\hline Border proximity & $-12,0$ & 2,3 & 2,2 & $-5,4$ & 0,000 & 1,13 \\
\hline $\begin{array}{l}\text { Overcrowded living } \\
\text { quarters }\end{array}$ & 131,9 & 34,0 & 40,4 & 3,3 & 0,001 & 1,40 \\
\hline $\begin{array}{l}\text { Persons employed in } \\
\text { manufacturing } \\
\text { establishments }\end{array}$ & 53,0 & 6,7 & 9,9 & 5,4 & 0,000 & 1,13 \\
\hline $\begin{array}{l}\text { Persons employed in } \\
\text { construction } \\
\text { establishments }\end{array}$ & 54,4 & 16,3 & 14,5 & 3,8 & 0,000 & 1,13 \\
\hline $\begin{array}{l}\text { Social care units } \\
\text { beds }\end{array}$ & 0,0 & 0,0 & 0,0 & $-0,3$ & 0,777 & 1,51 \\
\hline $\begin{array}{l}\text { People commuting to } \\
\text { the municipality to } \\
\text { work or study }\end{array}$ & 15,5 & 10,9 & 10,3 & 1,5 & 0,135 & 1,22 \\
\hline
\end{tabular}

Source: authors' own elaboration 


\subsection{GWR Model}

The adjusted R2 values of the GWR models are of 60\% (three times higher than the OLS model), ranging from 0.06 to 0.60 , with an $\mathrm{AIC}$ value of 4693 (lower that the OLS models, indicating a more suitable model) (Figure 4). The parameter estimation results of the GWR model are displayed in Table 3 and the local GWR coefficients can be found in Figure 5.

Table 3. GWR model results

\begin{tabular}{|l|c|c|c|c|}
\hline \multirow{2}{*}{ VARIABLE } & \multicolumn{2}{c|}{ COEFFICIENTS } & \multicolumn{2}{c|}{ STD. ERROR } \\
\cline { 2 - 5 } & Lower & Upper & Lower & Upper \\
\hline Intercept & -573.08 & 4729.00 & 621.15 & 1067.91 \\
\hline Border proximity & -33.11 & 6.75 & 2.85 & 5.43 \\
\hline Overcrowded living quarters & -216.95 & 451.33 & 45.51 & 88.06 \\
\hline $\begin{array}{l}\text { Persons employed in manufacturing } \\
\text { establishments }\end{array}$ & -33.62 & 73.94 & 7.62 & 16.42 \\
\hline $\begin{array}{l}\text { Persons employed in construction } \\
\text { establishments }\end{array}$ & -33.73 & 42.79 & 16.88 & 39.55 \\
\hline Social care units' beds & -0.05 & 0.09 & 0.02 & 0.04 \\
\hline $\begin{array}{l}\text { People commuting to the municipality to } \\
\text { work or study }\end{array}$ & -36.02 & 49.77 & 11.90 & 30.50 \\
\hline
\end{tabular}

Source: authors' own elaboration

Figure 5. Geographic distribution of local R2 of GWR

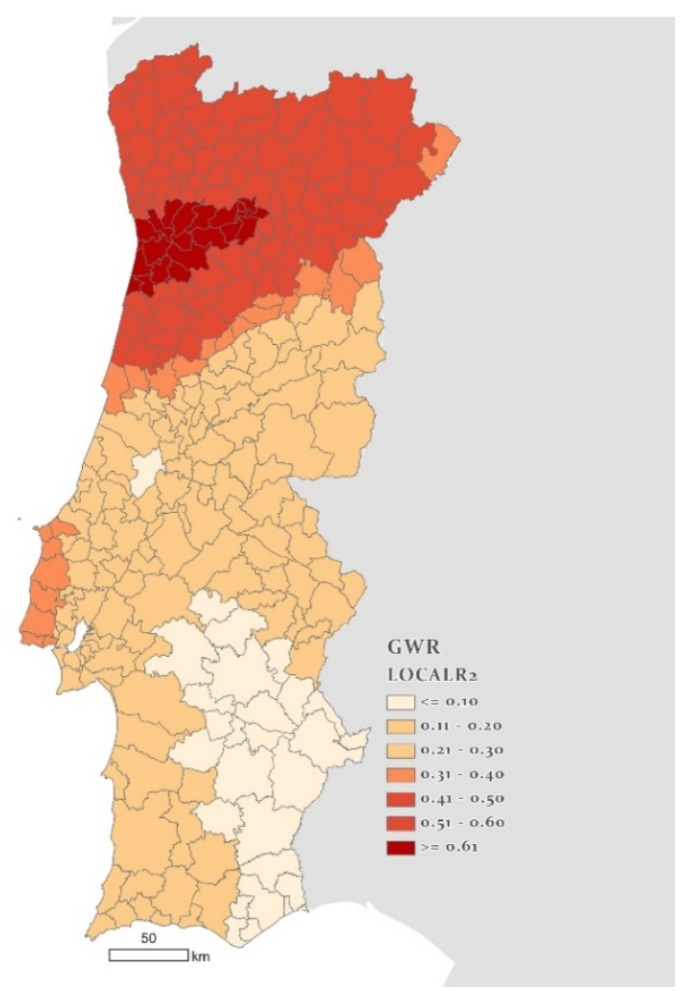

Source: authors' own elaboration 
Figure 6. Geographic distribution of GWR coefficients
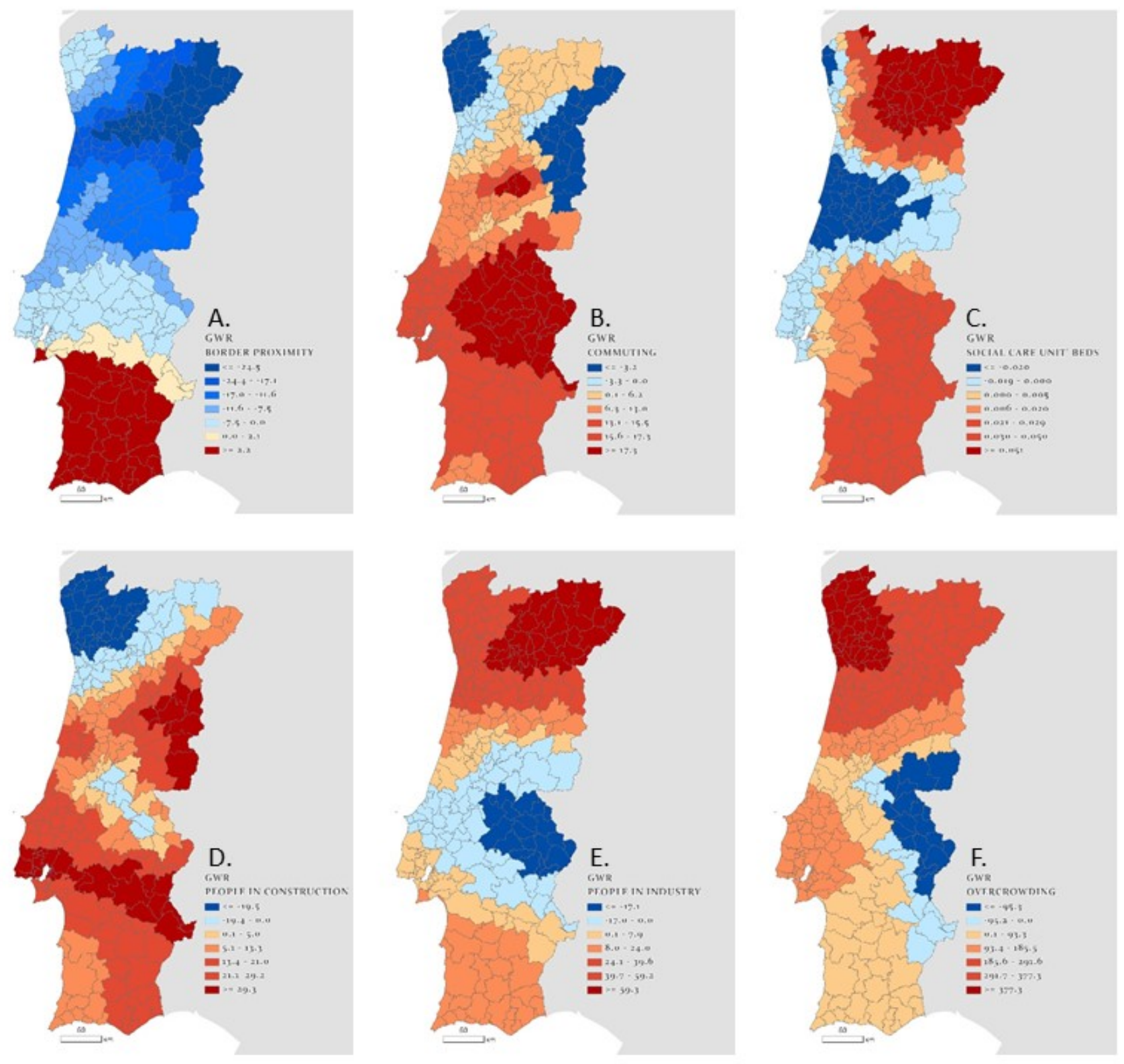

Key: A. Time to reach the Border with Spain, weighted by population distribution; B. People commuting to the municipality to work or study (\%); C. Social care units' beds (/100.000 elders); D. Persons employed in construction establishments (\%); E. Persons employed in manufacturing establishments (\%); F. Proportion of overcrowded living quarters (\%).

Source: authors' own elaboration

The model capacity to explain the COVID-19 was higher in the North of the country and the metropolitan areas, whereas R2 values $>0.3$ were found; the model performance decreases in the southern municipalities. 
Local GWR coefficients provide information about the changing tendency in the age standardized COVID-19 incidence rate by a unit change in the independent variables. The overcrowded living quarter's coefficients reveal a positive association across the majority of the country, indicating that COVID-19 incidence tends to be higher in municipalities with higher overcrowding. The positive correlation coefficients were extensively and noticeably higher along the north region and the two main metropolitan areas.

Persons employed in manufacturing establishments are positively associated with the COVID-19 incidence rate in the municipalities from the North region, being an important factor to explain the high rates verified in these municipalities.

Persons employed in construction establishments influence on the epidemic situation importantly varies across the country. The municipalities from the Centre and South, since the Spanish border until the Atlantic shore, tend to present important positive association, while in the municipalities from the North Atlantic shore is not a relevant factor.

The percentage of people commuting to the municipality to work or study has a positive association with COVID-19 incidence in the majority of the country, being particularly important in the municipalities from the Lisbon Metropolitan Area and near the border with Spain at the Centre and South of the country.

The number of Social care units' beds per 100,000 elderly was revealed to be an important predictor in the border municipalities from the North and South, but not in the Centre or in the municipalities from the Atlantic shore.

The proximity to the border was associated in the municipalities from the North and Centre, where being near the border (less distant) was associated with higher COVID-19 incidence. In the municipalities from the South this association was less important or even in the opposite direction.

\section{Discussion}

This study addressed the impacts of socioeconomic conditions on COVID-19 incidence and how they vary across the country applying GWR models. Six variables that potentially could explain the spatial pattern of age-standardized COVID-19 incidence rate at the municipal level across Portugal were compiled. Our findings suggest that the role of each analysed factor varies importantly across the country. Evidence to identify corresponding locations where these factors shed significant influences was provided. 
In Portugal the first cases of COVID-19 were detected on the $2^{\text {nd }}$ of March, ten days later, on the $12^{\text {th }}$, the first measures were implemented, and on the $18^{\text {th }}$ the emergency state was decreed, imposing stronger containment measures, such as mandatory confinement (Almendra et al. 2021; Moniz et al. 2021). The adopted measures resulted in a relatively mild first wave, but failed to avoid the second, registered at the latest months of 2020.

Portugal is a country marked by strong demographic, economic and social inequalities (Almendra et al., 2017; Claudia Costa et al., 2020; Costa \& Santana, 2021; Moura \& Barros, 2018; Santana \& Almendra, 2018) and it is without surprise that the COVID-19 incidence rate presents a spatial heterogeneous pattern. Until the end of 2020, the incidence rate was higher in the North municipalities and in the Lisbon Metropolitan Areas and lower in the municipalities from the South.

In the global model, border proximity, proportion of overcrowded living quarters, persons employed in manufacturing establishments and persons employed in construction establishments were found to be significant predictors, while, despite presenting the expected behaviour, the association between COVID-19 incidence and Social care units' beds and people commuting to the municipality to work or study are not significant. Some of the dimensions addressed have been previously identified as socio-territorial structures with potential influence on contagion and mortality in Portugal by Marques et al. (2020).

By modelling the role played by the studied factors, accounting for the possibility that its influence may change across the country, it was possible to identify that municipalities are affected differently by the same factor, and that this varying influence has identifiable geographical patterns. This spatial heterogeneity in the model coefficients was also found in previous studies addressing the impact of multidimensional factors on the pandemic geography (Li et al., 2020; Mogi \& Spijker, 2021; Mollalo et al., 2020).

Almendra et al. (2021), in a study assessing the spatiotemporal pattern of COVID-19 incidence during the first wave, identified a common cluster of high cases between Portugal and Spain in the Norther border of Portugal. In this study, the authors further test the hypothesis that economic and social border relationships between Portugal and Spain could have some impact in the COVID-19 incidence and spread of the disease. It was identified that this factor plays a more important role in the municipalities from the North and Centre Region suggesting that border relationships may be stronger in the North and Centre. 
The percentage of persons employed in manufacturing establishments is an important factor in the North region near the Atlantic Ocean and the percentage of persons employed in construction establishments in the North and Centre regions. The rational beyond these indicators shows that certain jobs are impossible to adapt to homework, and need to be developed in environments that favour close contact between colleagues, therefore favouring new infections (Pasco et al., 2020). Nonetheless, the conditions in which manufacturing is processed vary significantly. The activities developed in the Northern Region may have been more favourable for new infections than the main activities in other municipalities. Future studies need to identify which activities are more favourable for new coronavirus infections.

People living in overcrowded households was considered an important factor in the municipalities of the two metropolitan areas; mostly the municipalities from Porto Metropolitan Area. Overcrowded quarters are often places with limited ventilation and density of persons by household which provide close contact between individuals, representing the perfect context for the interaction of the drivers of transmission (Dalziel et al., 2018; Sharifi \& Khavarian-Garmsir, 2020). Lai, Leone, and Zopp (2020) analysed the impact of Covid-19-related social living conditions on spatial planning policies and practices and highlight the need of avoiding overcrowding houses, promoting a balanced distribution of activities, amenities and outdoor public meeting spaces of small- or medium-size.

Elderly are more vulnerable to COVID-19 infection and their survival rate is lower (Baud et al., 2020; Dowd et al., 2020; Laires \& Nunes, 2020; Marques et al., 2020; Sannigrahi et al., 2020). A recent cross country study has shown that more than a half of the variation in mortality rates can be explained by differences in the population age structure (Dudel et al., 2020). The COVID-19-age related vulnerability is even more severe when considering retirement homes and long-term facilities for dependent elderly where is very difficult to stop the spread of the disease (Etard et al., 2020). According to Team and Manderson (2020), institutional care is routinely, constrained by the capacity of residents to pay, by poor funding support, understaffing, and overcrowding; aged care workers are commonly undertrained, under-protected, underpaid and underemployed, working on a contract basis across multiple facilities, ineligible for paid sick and isolation leave; residents often share bed-rooms, meal rooms and bathrooms, and share equipment such as wheelchairs and commodes. Portuguese social communication has been reporting several cases of COVID-19 outbreaks in retirement homes and our results identified that Social care units' beds are important predictors of COVID-19 incidence rate in the border 
municipalities from the North and South. Previous studies in Portugal have identified retirement homes as an important factor (da Costa \& da Costa, 2020).

The percentage of people commuting to the municipality to work or study is an important factor across the country, but assumes particular importance in the municipalities around the Lisbon Metropolitan Area. Despite the measures taken to diminish the capacity of public transportation and to promote the usage of mask in public spaces, daily commuting through public transportation is perceived as a favourable factor for the spread of virus (Troko et al., 2011) as it promotes risk contact (Kang et al., 2020; Severo et al., 2021). According to Lai et al. (2020), in the future, places will need to ensure that residents may work and study in the same municipality where they live. Moreover, alternative modes of transportation meant for individual use will be more popular (e.g. bike) (Gerlofs-Nijland et al., 2021).

\section{Strengths and limitations}

To our best knowledge, this paper provides the first attempt to use GWR models of COVID-19 distribution across Portugal and can provide useful insights for policymakers for targeted interventions and for proper identification of risk factors.

Although the model provides evidence on the socioeconomic factors associated with COVID-19 incidence, the geographical pattern is not fully explained. Beside the six variables presented, 14 other variables were considered for the analysis but were not selected by the model, namely: population density, elderly living in institutionalized families dedicated to social care, nonqualified workers, ageing ratio, share of elderly population, population with tertiary education attainment, average monthly earnings of salaried employees, dynamism related to the municipality purchasing power, unemployment rate, people commuting to another municipality to work or study, hospital admissions due to diseases of the respiratory system, hospital admissions due to Diabetes, mortality due to respiratory diseases and geographical accessibility to the reference hospital (weighted by population distribution). Other factors might affect the spatial pattern of the COVID-19 incidence and were not addressed. Also, dimensions as the local policies, people's behaviour or different strains of the virus were not assessed and contribute for different rhythms of spreading and uneven incidence. Furthermore, important variables considered in this text are only available for 2011 and may not be as accurate as desirable.

Although the results presented should not be derived to region with different social, demographic, economic contexts without caution, the methods applied in this text can be 
implemented in different geographical frameworks, to consider the different waves and cover diverse scales of analysis. It is important to highlight that these results are linked with the scale of analysis selected; the role of environmental factors at a neighbourhood scale are still to be addressed, as far as the authors are aware.

\section{Conclusion}

This study found that in Portugal the association between age-standardized COVID-19 incidence rate and socioeconomic conditions varies unevenly across the country. It highlights the role of border proximity, proportion of overcrowded living quarters, persons employed in manufacturing establishments and persons employed in construction establishments as significant COVID-19 predictors. Still, with different weights depending on the geographical area.

The results presented provide useful insights for policymakers for targeted local interventions and for proper identification of risk factors. Thus, empowering the municipalities with local evidence will allow them to tackle COVID-19 and its consequences.

Acknowledgements: RA, PS and CC are members of CEGOT, which is supported by National Funds through the FCT under Grant UIDB/04084/2020.

Authorship statement: The authors declare no conflict of interest. The participation of the authors in the article is as follows. Study design: RA, PS; Methodology: RA, CC; Project administration: PS; Writing: RA, PS, CC. 


\section{References}

Adegboye, O.A., Adekunle, A. I., Pak, A., Gayawan, E., Leung, D.H., Rojas, D.P., Elfaki, F., McBryde, E.S., \& Eisen, D.P. (2021). Change in outbreak epicentre and its impact on the importation risks of COVID-19 progression: A modelling study. Travel Medicine and Infectious Disease, 40, 101988. https://doi.org/10.1016/j.tmaid.2021.101988

Adegboye, O.A., Adekunle, A.I., Pak, A., Gayawan, E., Leung, D.H.Y., Rojas, D.P., Elfaki, F., McBryde, E.S., \& Eisen, D.P. (2020). Change in outbreak epicenter and its impact on the importation risks of COVID-19 progression: A modelling study. MedRxiv, 2020.03.17.20036681. https://doi.org/10.1101/2020.03.17.20036681

Almeida, D., Leão, T., \& Barros, H. (2020). COVID-19: Papel dos portos e aeroportos na transmissão da doença. In M. Tavares \& C. Silva (Eds.), Da emergência de um novo vírus humano à disseminação global de uma nova doença - Doença por Coronavírus 2019 (ISPUP, pp. 1-9). ISPUP

http://asset.youoncdn.com/ab296ab30c207ac641882479782c6c34/ac59ce2a887db045865 2a65c82b50e97.pdf

Almendra, R., Santana, P., Santurtún, A., \& Fdez-Arroyabe, P. (2021). COVID-19 Spread in the Iberian Peninsula during the "First Wave": Spatiotemporal Analysis. In R. Akhtar (Ed.), Coronavirus (COVID-19) Outbreaks, Environment and Human Behaviour (Springer N, pp. 269282). https://doi.org/10.1007/978-3-030-68120-3_16

Almendra, R., Santana, P., \& Vasconcelos, J. (2017). Evidence of social deprivation on the spatial patterns of excess winter mortality. International Journal of Public Health, 62(8), 849856. https://doi.org/10.1007/s00038-017-0964-7

Baud, D., Qi, X., Nielsen-Saines, K., Musso, D., Pomar, L., \& Favre, G. (2020). Real estimates of mortality following COVID-19 infection. In The Lancet Infectious Diseases. https://doi.org/10.1016/S1473-3099(20)30195-X

Brooks, S. K., Webster, R. K., Smith, L. E., Woodland, L., Wessely, S., Greenberg, N., \& Rubin, G. J. (2020). The psychological impact of quarantine and how to reduce it: rapid review of the evidence. Lancet (London, England), 395(10227), 912-920. https://doi.org/10.1016/S0140$\underline{6736(20) 30460-8}$

Chung, C. K. L., Xu, J., \& Zhang, M. (2020). Geographies of Covid-19: how space and virus shape each other. In Asian Geographer. https://doi.org/10.1080/10225706.2020.1767423 
Conticini, E., Frediani, B., \& Caro, D. (2020). Can atmospheric pollution be considered a cofactor in extremely high level of SARS-CoV-2 lethality in Northern Italy? In Environmental Pollution. https://doi.org/10.1016/j.envpol.2020.114465

Costa, C., Tenedório, J.A., \& Santana, P. (2020). Disparities in geographical access to hospitals in Portugal. ISPRS International Journal of Geo-Information, 9(10). https://doi.org/10.3390/ijgi9100567

Costa, C., Freitas, A., Almendra, R., \& Santana, P. (2020). The Association between Material Deprivation and Avoidable Mortality in Lisbon, Portugal. International Journal of Environmental Research and Public Health, 17(22), 8517. https://doi.org/10.3390/ijerph17228517

Costa, Cláudia, \& Santana, P. (2021). Gender and Age Differences in Socio-economic Inequalities in Total and Avoidable Mortality in Portugal: A Trend Analysis*. Fiscal Studies, 42(1), 123-145. https://doi.org/10.1111/1475-5890.12264

da Costa, E.M., \& da Costa, N.M. (2020). The Covid-19 Pandemic Process In Mainland Portugal. A Geographical Analysis Of The First 100 Days. Finisterra, 55(115), 11 18. https://doi.org/10.18055/Finis20361

Dalziel, B.D., Kissler, S., Gog, J.R., Viboud, C., Bjørnstad, O.N., Metcalf, C.J.E., \& Grenfell, B.T. (2018). Urbanization and humidity shape the intensity of influenza epidemics in U.S. cities. Science, 362(6410), 75-79. https://doi.org/10.1126/science.aat6030

Daszak, P., Amuasi, J., Neves, C., Hayman, D., Kuiken, T., Roche, B., Zambrana-Torrelio, C., Buss, P., Dundarova, H., Feferholtz, Y., Földvári, G., Igbinosa, E., Junglen, S., Liu, Q., Suzan, G., Uhart, M., Wannous, C., Woolaston, K., Mosig Reidl, P., ... Ngo, H. T. (2020). Workshop Report on Biodiversity and Pandemics of the Intergovernmental Platform on Biodiversity and Ecosystem Services. IPBES secretariat. https://doi.org/10.5281/zenodo.4147317

Dowd, J.B., Rotondi, V., Andriano, L., Brazel, D.M., Block, P., Ding, X., Liu, Y., \& Mills, M.C. (2020). Demographic science aids in understanding the spread and fatality rates of COVID-19. MedRxiv, 2020.03.15.20036293. https://doi.org/10.1101/2020.03.15.20036293

Dudel, C., Riffe, T., Acosta, E., van Raalte, A., Strozza, C., \& Myrskylä, M. (2020). Monitoring trends and differences in COVID-19 case-fatality rates using decomposition methods: Contributions of age structure and age-specific fatality. PLOS ONE, 15(9 September). https://doi.org/10.1371/journal.pone.0238904 
Etard, J. F., Vanhems, P., Atlani-Duault, L., \& Ecochard, R. (2020). Potential lethal outbreak of coronavirus disease (COVID-19) among the elderly in retirement homes and long-term facilities, France, March 2020. In Eurosurveillance, 25(15). European Centre for Disease Prevention and Control (ECDC). https://doi.org/10.2807/1560-7917.ES.2020.25.15.2000448

Flaxman, S., Mishra, S., Gandy, A., Unwin, H. J. T., Mellan, T. A., Coupland, H., Whittaker, C., Zhu, H., Berah, T., Eaton, J. W., Monod, M., Perez-Guzman, P. N., Schmit, N., Cilloni, L., Ainslie, K. E. C., Baguelin, M., Boonyasiri, A., Boyd, O., Cattarino, L., ... Bhatt, S. (2020). Estimating the effects of non-pharmaceutical interventions on COVID-19 in Europe. Nature, 584(7820), 257-261. https://doi.org/10.1038/s41586-020-2405-7

Gardner, W., States, D., \& Bagley, N. (2020). The Coronavirus and the Risks to the Elderly in Long-Term Care. Journal of Aging \& Social Policy, 32(4-5), 310315. https://doi.org/10.1080/08959420.2020.1750543

Gerlofs-Nijland, M., Staatsen, B., Geelen, L., Mulder, Y., Fuse, V., Sharashidze, N., Bonvoisin, N., Mee Choi, A. K., \& Fruianu, M. (Eds.) (2021). Road transport facts and figures: How healthy and environmentally friendly is our transport today? Government of the Netherlands, The PEP, UNECE \& WHO. https://thepep.unece.org/node/824

Gu, K., Zhou, Y., Sun, H., Dong, F., \& Zhao, L. (2021). Spatial distribution and determinants of PM2.5 in China's cities: fresh evidence from IDW and GWR. Environmental Monitoring and Assessment, 193(1), 1-22. https://doi.org/10.1007/s10661-020-08749-6

Horton, R. (2020). Offline: COVID-19 is not a pandemic. The Lancet, 396(10255), 874. https://doi.org/10.1016/S0140-6736(20)32000-6

Huisman, M., Kunst, A. E., Bopp, M., Borgan, J.-K., Borrell, C., Costa, G., Deboosere, P., Gadeyne, S., Glickman, M., Marinacci, C., Minder, C., Regidor, E., Valkonen, T., \& Mackenbach, J. P. (2005). Educational inequalities in cause-specific mortality in middle-aged and older men and women in eight western European populations. The Lancet, 365(9458), 493500. https://doi.org/10.1016/S0140-6736(05)17867-2

Kang, D., Choi, H., Kim, J.-H., \& Choi, J. (2020). Spatial epidemic dynamics of the COVID-19 outbreak in China. International Journal of Infectious Diseases. https://doi.org/10.1016/j.ijid.2020.03.076

Knudsen, A.K.S., Stene-Larsen, K., Gustavson, K., Hotopf, M., Kessler, R. C., Krokstad, S., Skogen, J.C., Øverland, S., \& Reneflot, A. (2021). Prevalence of mental disorders, suicidal 
ideation and suicides in the general population before and during the COVID-19 pandemic in Norway: A population-based repeated cross-sectional analysis. The Lancet Regional HealthEurope, 4, 100071. https://doi.org/10.1016/j.lanepe.2021.100071

Kulu, H., \& Dorey, P. (2021). Infection rates from Covid-19 in Great Britain by geographical units: A model-based estimation from mortality data. Health and Place. https://doi.org/10.1016/j.healthplace.2020.102460

Lai, S., Leone, F., \& Zoppi, C. (2020). Covid-19 and spatial planning A few issues concerning public policy. Tema-Journal of Land Use Mobility and Environment, June, 231-246.

Laires, P. A., \& Nunes, C. (2020). Population-based Estimates for High Risk of Severe COVID-19 Disease due to Age and Underlying Health Conditions. Acta Medica Portuguesa, 33(13), 720725. https://doi.org/10.20344/AMP.14222

Li, X., Zhou, L., Jia, T., Peng, R., Fu, X., \& Zou, Y. (2020). Associating COVID-19 severity with urban factors: A case study of Wuhan. International Journal of Environmental Research and Public Health, 17(18), 1-20. https://doi.org/10.3390/ijerph17186712

Loureiro, A., Santana, P., Nunes, C., \& Almendra, R. (2019). The Role of Individual and Neighborhood Characteristics on Mental Health after a Period of Economic Crisis in the Lisbon Region (Portugal): A Multilevel Analysis. International Journal of Environmental Research and Public Health, 16(15), 1-16. https://doi.org/10.3390/ijerph16152647

Marques, T.S., Santos, H., Honório, F., Ferreira, M., Ribeiro, D., \& Torres, M. (2020). The Territorial Mosaic Of Contagion And Mortality Risk By Covid-19 In Mainland Portugal. Finisterra, 55(115), 19-26. https://doi.org/10.18055/Finis20383

Menéndez, E.P., \& Higueras García, E. (2020). Urban Sustainability Versus the Impact of Covid19: A Madrid Case Study. DISP. https://doi.org/10.1080/02513625.2020.1906059

Mogi, R., \& Spijker, J. (2021). The influence of social and economic ties to the spread of COVID19 in Europe. Journal of Population Research, 1-17. https://doi.org/10.1007/s12546-021$\underline{09257-1}$

Mollalo, A., Vahedi, B., \& Rivera, K.M. (2020). GIS-based spatial modeling of COVID-19 incidence rate in the continental United States. Science of the Total Environment, 728, 138884. https://doi.org/10.1016/j.scitotenv.2020.138884 
Moniz, M., Soares, P., \& Nunes, C. (2021). COVID-19 Transmission Dynamics: A Space-andTime Approach. Portuguese Journal of Public Health, 38(1), 4046. https://doi.org/10.1159/000515535

Moura, A., \& Barros, P.P. (2018). Are socioeconomic inequalities in the process of registration with family physicians decreasing in Portugal? Acta Medica Portuguesa, 37(12), 730737. https://doi.org/10.20344/amp.9873

Murgante, B., Balletto, G., Borruso, G., Casas, G. Las, Castiglia, P., \& Dettori, M. (2020). Geographical analyses of Covid-19's spreading contagion in the challenge of global health risks The role of urban and regional planning for risk containment. TeMA. Journal of Land Use, Mobility and Environment, special issue, 283-304. https://doi.org/10.6092/1970-9870/6849

OECD (2018). OECD Regions and Cities at a Glance 2018. https://doi.org/10.1787/97dcb4c9-en

Pasco, R.F., Fox, S.J., Johnston, S.C., Pignone, M., \& Meyers, L.A. (2020). Estimated Association of Construction Work with Risks of COVID-19 Infection and Hospitalization in Texas. JAMA Network Open, 3(10). https://doi.org/10.1001/jamanetworkopen.2020.26373

Ribeiro, A.I., \& Santos, C.J. (2020). The Importance Of Spatial Analysis Of Covid-19 Pandemic For Health Geography: Challenges And Perspectives. Finisterra, 55(115), 3742. https://doi.org/10.18055/Finis20318

Roquette, R., Nunes, B., \& Painho, M. (2018). The relevance of spatial aggregation level and of applied methods in the analysis of geographical distribution of cancer mortality in mainland Portugal (2009-2013). Population Health Metrics, 16(1), 6. https://doi.org/10.1186/s12963$\underline{018-0164-6}$

Sanchez-Lorenzo, A., Vaquero-Martínez, J., Calbó, J., Wild, M., Santurtún, A., Lopez-Bustins, J. A., Vaquero, J. M., Folini, D., \& Antón, M. (2021). Did anomalous atmospheric circulation favor the spread of COVID-19 in Europe? Environmental Research, 194. https://doi.org/10.1016/j.envres.2020.110626

Sannigrahi, S., Pilla, F., Basu, B., Basu, A. S., \& Molter, A. (2020). Examining the association between socio-demographic composition and COVID-19 fatalities in the European region using spatial regression approach. Sustainable Cities and Society, 62, 102418. https://doi.org/10.1016/j.scs.2020.102418 
Santana, P., \& Almendra, R. (2018). The health of the Portuguese over the last four decades. Méditerranée, 130. https://doi.org/10.4000/mediterranee.10348

Santana, P., \& Almendra, R. (2019). Inequalities in inability to keep the home adequately cool in summer. In W.R.O. for Europe (Ed.), Environmental health inequalities in Europe. Second assessment report (WHO Region, pp. 35-39). WHO.

Santana, P., Costa, C., Cardoso, G., Loureiro, A., \& Ferrão, J. (2015). Suicide in Portugal: Spatial determinants in a context of economic crisis. Health and Place, 35, 8594. https://doi.org/10.1016/j.healthplace.2015.07.001

Santana, P., Costa, C., Marí-Dell'Olmo, M., Gotsens, M., Borrell, C., Marí-Dell'Olmo, M., Gotsens, M., \& Borrell, C. (2015). Mortality, material deprivation and urbanization: exploring the social patterns of a metropolitan area. International Journal for Equity in Health, 14(1), 55. https://doi.org/10.1186/s12939-015-0182-y

Santana, P., Freitas, Â., Costa, C., Stefanik, I., Santinha, G., Krafft, T., \& Pilot, E. (2020). The Role of Cohesion Policy Funds in Decreasing the Health Gaps Measured by the EURO-HEALTHY Population Health Index. International Journal of Environmental Research and Public Health, 17(5), 1567. https://doi.org/10.3390/ijerph17051567

Setti, L., Passarini, F., De Gennaro, G., Barbieri, P., Licen, S., Perrone, M.G., Piazzalunga, A., Borelli, M., Palmisani, J., Di Gilio, A., Rizzo, E., Colao, A., Piscitelli, P., \& Miani, A. (2020). Potential role of particulate matter in the spreading of COVID-19 in Northern Italy: first observational study based on initial epidemic diffusion. BMJ Open, 10(9), e039338. https://doi.org/10.1136/bmjopen-2020-039338

Severo, M., Ribeiro, A.I., Lucas, R., Leão, T., \& Barros, H. (2021). Urban Rail Transportation and SARS-Cov-2 Infections: An Ecological Study in the Lisbon Metropolitan Area. Frontiers in Public Health, 9, 611565. https://doi.org/10.3389/fpubh.2021.611565

Sharifi, A., \& Khavarian-Garmsir, A. R. (2020). The COVID-19 pandemic: Impacts on cities and major lessons for urban planning, design, and management. In Science of the Total Environment (vol. 749, p. 142391). Elsevier B.V. https://doi.org/10.1016/j.scitotenv.2020.142391

Sironi, M., Hasnain, S.E., Rosenthal, B., Phan, T., Luciani, F., Shaw, M.A., Sallum, M.A., Mirhashemi, M. E., Morand, S., \& González-Candelas, F. (2020). SARS-CoV-2 and COVID-19: A genetic, epidemiological, and evolutionary perspective. In Infection, Genetics and Evolution. https://doi.org/10.1016/j.meegid.2020.104384 
Smit, A. J., Fitchett, J.M., Engelbrecht, F.A., Scholes, R.J., Dzhivhuho, G., \& Sweijd, N.A. (2020). Winter is coming: A southern hemisphere perspective of the environmental drivers of sars-cov-2 and the potential seasonality of covid-19. International Journal of Environmental Research and Public Health, 17(16), 1-28. https://doi.org/10.3390/ijerph17165634

Team, V., \& Manderson, L. (2020). How COVID-19 Reveals Structures of Vulnerability. Medical Anthropology: Cross Cultural Studies in Health and Illness, 39(8), 671674. https://doi.org/10.1080/01459740.2020.1830281

Timmis, K., \& Brüssow, H. (2020). The COVID-19 pandemic: some lessons learned about crisis preparedness and management, and the need for international benchmarking to reduce deficits. Environmental Microbiology, 22(6), 1986-1996. https://doi.org/10.1111/1462-2920.15029

Troko, J., Myles, P., Gibson, J., Hashim, A., Enstone, J., Kingdon, S., Packham, C., Amin, S., Hayward, A., \& Van-Tam, J.N. (2011). Is public transport a risk factor for acute respiratory infection? BMC Infectious Diseases. https://doi.org/10.1186/1471-2334-11-16

Volpato, S., Landi, F., \& Incalzi, R. A. (2020). A Frail Health Care System for an Old Population: Lesson form the COVID-19 Outbreak in Italy. Journals of Gerontology - Series A Biological Sciences and Medical Sciences, 75(9), e126-e127. Oxford University Press. https://doi.org/10.1093/gerona/glaa087

Wang, C., Pan, R., Wan, X., Tan, Y., Xu, L., Ho, C.S., \& Ho, R.C. (2020). Immediate Psychological Responses and Associated Factors during the Initial Stage of the 2019 Coronavirus Disease (COVID-19) Epidemic among the General Population in China. International Journal of Environmental Research and Public Health, 17(5). https://doi.org/10.3390/ijerph17051729

Wang, Z., \& Tang, K. (2020). Combating COVID-19: health equity matters. Nature Medicine, 26(458). https://doi.org/10.1038/s41591-020-0823-6

Weisent, J., Rohrbach, B., Dunn, J.R., \& Odoi, A. (2012). Socioeconomic determinants of geographic disparities in campylobacteriosis risk: A comparison of global and local modeling approaches. International Journal of Health Geographics, 17(45). https://doi.org/10.1186/1476$\underline{072 X-11-45}$

Zhu, Y., Xie, J., Huang, F., \& Cao, L. (2020). Association between short-term exposure to air pollution and COVID-19 infection: Evidence from China. Science of The Total Environment, 727, 138704. https://doi.org/10.1016/j.scitotenv.2020.138704 